\title{
Inclusion of Disabled Children in General Schools in Puducherry
}

\author{
S.Vidhyanathan ${ }^{1}$, Dr. K. Devan ${ }^{2}$ \\ Centre for Adult and Continuing Education,Pondicherry University
}

\begin{abstract}
Recent days, the concept of mainstreaming special children in general schools has gradually been taking root across the country's educational system, disabled children in particular. In 1974, a major shift in education for the children with disability was achieved with the launch of the comprehensive integrated education of the disabled children (IEDC).This scheme was implemented in 15000 schools in 26 states and Union territories of India and reportedly covered 65, 000 children with disabilities in mainstream schools. The scheme provides facilities in the form of books, stationery, uniforms and allowances for transport, reader, escort, etc. In spite of all these facilities, IEDC ends with limited success. However it was successful in creating awareness as the importance of integrating disabled children in the mainstream education. But only with the formulation of National Policy on Education (NPE), 1986, inclusive education for disabled children were treated as an imperative, besides the national policy for persons with disabilities was adopted in 1993, emphasized the need for mainstreaming of the persons with disabilities in the general educational system. National Policy on Education (NPE) also enabled the setting up of a team of experts under the chairmanship of Behrual Islam in 1987 to study the problems of disabled children and became the core of the comprehensive legislation provided later in the disabilities act of 1995. In this context District Primary Education Programme (DPEP) and Sarva Shiksha Abhiyan (SSA) were providedmajor thrust to integrate and include disabled children in the mainstream education. Currently Sarva Shiksha Abhiyan successfully implemented inclusive education for disabled children in India. Its ultimate aim is to provide universal elementary education. In-fact inclusion of one of the groups, which is extremely crucial for UEE, is perhaps that of the CWSN. Hence, the mainstreaming the education of CWSN is an important intervention in the present scenario. Thus this paper attempts to analyses the inclusion of children with special needs in general schools in Puducherry UT

Key words: Disabled Children, CWSN, SSA, Inclusion, General schools
\end{abstract}

\section{Introduction}

In ancient times, the disabled children were treated as unwanted andthey were segregated from nondisabled children. They were neglected by the parents, community and peers, etc., and treated them as inferior. They were not provided adequate educational facilities and supporting system. Frampton and Gall(1955) observed that while there was no conducive evidence, but abandonment of disabled was a universal practice in the ancient society, it was claimed that handicapped individuals were not being given due attention. By the middle of the $19^{\text {th }}$ century, several institutions-commonly referred to as asylums or sometimes as schools were established to benefit citizens with disabilities, there they were treated with compassion and sympathy under the influence of religious prescriptions. These facilities provided primarily protective care and management rather than treatment and education. In France, the year 1785 witnessed the first school for the blind started by valentine Huay in Paris. Father D'Lepse developed an early version of manual alphabet using finger spelling for the deaf. In Germany, Samuel Heinick developed an oral method of instruction for the deaf children. In the United States of America, the first permanent school for the deaf was set up in 1817 at Hartford, Connecticut. In 1829, Louis Braille developed the system of raised point alphabet using six dots arranged in two parallel rows of three dots, each was a landmark in the education of the blind.In India, the first school for the deaf was set up in Bombay in 1833 and the first school for the blind in Amritsar in 1887.

Along with the other parts of the world, the concept of mainstreaming of disabled has gradually been taking root in the country's educational system. In 1974 a major shift in education for the children with disability was achieved with the launch of the comprehensive integrated education of the disabled children (IEDC). The aim was to provide children with moderate disabilities with both facilities and financial support. This was implemented in 15000 schools in 26 states and Union territories of India and reportedly covered 65, 000 children with disabilities in mainstream schools. The scheme provides facilities in the form of books, stationery, uniforms and allowances for transport, reader, escort, etc. In spite of all these facilities, IEDC ends with limited success. However it was successful in creating awareness as the importance of integrating disabled children in the mainstream education. But only with the formulation of National Policy on Education (NPE), 1986, inclusive education for disabled children were treated as an imperative, besides the national policy for persons with disabilities was adopted in 1993, emphasized the need for mainstreaming of the persons with 
disabilities in the general education system. National Policy on Education (NPE) also enabled the setting up of a team of experts under the chairmanship of Behrual Islam in 1987 to study the problems of disabled children and became the core of the comprehensive legislation provided later in the disabilities act of 1995. In this context District Primary Education Programme (DPEP) and Sarva Shiksha Abhiyan (SSA) were provided major thrust to integrate and include disabled children in the mainstream educational system. Currently Sarva Shiksha Abhiyan successfully implemented inclusive education for disabled children in India. Its ultimate aim is to universalize elementary education. The inclusion of Disabled Children has further been facilitated by the Constitutional $\left(86^{\text {th }}\right.$ Amendment) Act, making free and compulsory elementary education a Fundamental Right, for all the children in the age group of 6-14 years. This Amendment has given a new thrust to the education of Children with Special Needs (CWSN), as without their inclusion, the objective of UEE cannot be achieved. Infact, inclusion of one of the groups, which is extremely crucial for UEE, is perhaps that of the CWSN. Hence, mainstreaming the education of CWSN is an important intervention in the present scenario.

\section{The Concept of Children with Special Needs and Its Types}

The concept of children with special needs is British origin. The Government of Britain appointed a commission under Baroness Mary Warnock to report about the status of Special education in Britain in the year 1978. Warnock reported that it was wrong to identify children by means of their "Handicap" and then send them to schools organised to deal with just such categories, rather the report states that they should identify their educational difficulties and provide accordingly. And so the term Special Educational Needs (SEN) entered UK legislation, its classrooms and importantly teachers thinking. In India, there is no such legal definition for Children with special needs exists in the constitution, but the Persons with Disabilities Act, 1995 defines the term disability and different types of disabilities. There are checklists available to identify the various disabilities and are currently used to identify special needs children. The children with special needs are unique individuals. Their specialty may be noticed in one or more of the following dimensions such as vision, hearing, communication, perceptual-motor, social-emotional, intelligence and adaptive behavior. These children were previously regarded as children with diverse abilities (both children with giftedness and disability, disturbances and disadvantages).The children with special needs are different from the Normal children either in the positive direction or in the negative direction. Consequently there are various types of children with special needs. They are:

Types of Children with Special Needs

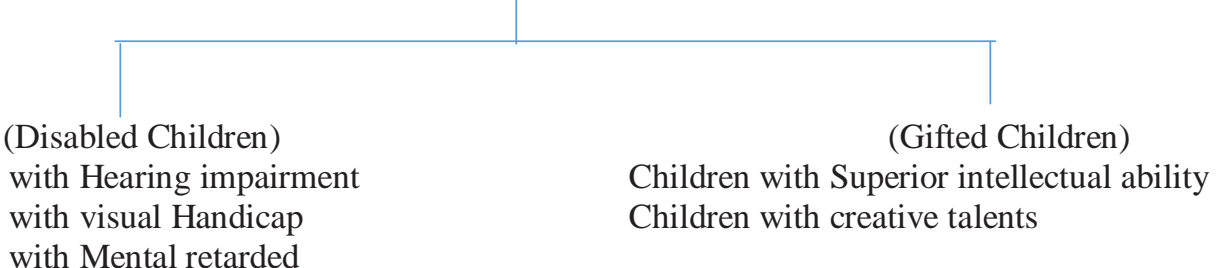

Children with visual Handicap

Children with Mental retarded

Children with speech handicap

Children with Multiple Disabilities

Children with Orthopedically Challenged

Children with emotional disturbances

Children with social disadvantages

Children with delinquent tendencies

Children with Learning disability

\section{Gifted Children}

Children possessing a high intellectual level and special abilities and talents are regarded as gifted child. Havighurst defines the talented or gifted child is one who shows consistently remarkable performance in any worthwhile line of endeavour. Gifted are those children whose cognitive abilities place them in the upper level of population distribution. They constitute only 3 to 5 percent of the population. The academically gifted has an I.Q of 130 and above. They have superior ability, creativeness in thinking and production. According to Guilford(1950), the gifted are those students whose potential intellectual powers are at such a high creational level in both production and evaluative thinking that it can be reasonably assumed, that they could be the future problem solvers, innovators, evaluators of the culture, if adequate educational experiences are provided( Kar, 1992).

\section{Disabled Children and Its Types}

The term disability does not have an easy commonly acceptable and precise definition. In simple terms, disability may be defined as a kind of impairment, physical or mental, that makes it difficult for a person to do 
what other people are able to do. World health organization (WHO) distinguished between impairment, disability and handicap:

1. An impairment means any loss of abnormality of psychological, physiological or anatomical structure of function.

2. A disability is a restriction of lack of resulting from impairment ability to perform an activity in a manner or within the range considered normal for a human being.

3. A handicap is a disadvantage for a given individual resulting from an impairment or disability that limits or prevents the fulfillment of a role that is considered normal for that individual.

According to NSSO, the disability means: "A person with restrictions or lack of abilities to perform an activity in the manner or within the range considered normal for a human being was treated as having disability/ it excluded illness/ injury of recent origin ( morbidity) resulting into temporary. Loss of ability to see, hear, and speak or more". According to the Government of India, Impairment is a permanent or transitory psychological or anatomical loss and or abnormality. For example, a missing or ineffective part, tissue or organ or mechanism of the body, such as an amputated limb, paralysis after polio, myocardial infarction, cerebral-vascular thrombosis, restricted pulmonary capacity, diabetes, myopia, disfigurement, mental retardation, hypertension, perceptual disturbances. Disability is defined as an existing difficulty in performing one or more activities which in accordance with the subject's age, sex and normative social role, are generally accepted as essential basic components of daily living, such as self-care social relations and economic activity, depending in part in the duration of the functional limitation disability may be short term, long term or permanent.

\section{Types of disability}

According to the persons with disability (equal opportunities) protection of rights and full participation act, 1995. Disability includes the following categories:

\section{Blindness}

1. Total absence of sight

2. Visual acuity not exceeding $6 / 60$ or $20 / 200$ (Snellen) in the better eye with correcting lenses

3. Limitation of the field of the vision subtending an angle of 20 degree or worse.

\section{Low vision}

Persons with low vision are those with impairment of visual functioning even after treatment of standard refracting correction but who uses or is potentially capable of using with appropriate for the planning of the execution of a task with appropriate assertive device.

\section{Leprosy Cured}

Leprosy Cured person means any person who has been cured of leprosy but is suffering from;

1. Loss of sensation in hands or feet as well as sensation and paresis in the eye and eye lit but with no manifest deformity.

2. Manifest deformity and paresis, but having sufficient mobility in their hands and feet to enable them to engage in normal activity.

3. Extreme physical deformity as well as advanced stage which prevents him from undertaking any gainful occupation and the expression "leprosy cured" shall be constructed accordingly.

\section{Hearing Impairment} of frequencies.

Hearing impairment means a loss of sixty decibels of more in the better ear in the conversational range

\section{Loco Motor Disability}

Loco motor disability means disability of the bones, joints, muscles leading to substantial restriction of the movement of the limbs or any form of cerebral palsy.

\section{Mental Retardation}

Mental retardation means a condition of arrested or incomplete development of mind of a person, which is specially characterized by sub normality of intelligence.

\section{Mental Illness}

Mental illness means any mental disorder other than mental retardation.

\section{Sarva Shiksha Abhiyan}

Sarva Shiksha Abhiyan (SSA) is the Government of India's flagship programme have been launched in the academic year 2001-02 at national level to achieve the main goal of Universalization of Elementary Education (UEE) through a time bound manner in collaboration with states and local governments, as mandated 
by the $86^{\text {th }}$ amendment of the constitution of India for making free and compulsory education to the children of 6-14 years age group. Sarva Shiksha Abhiyan covers the whole country and addresses the needs of 192 million children residing in 1.1 million habitations (SSA Framework for Implementation, 2011). It is the apt response to the demand for quality education and promoting social justice through basic education. It provides an opportunities for human capabilities of all children through provision of community owned education in a mission mode. SSA's main aim is to bridge social, regional and gender gaps and its special focus on disabled children with the active participation of community in the management of schools.(Puducherry Annual Report, 2010-2011). It is the apt response to the demand for quality education and promoting social justice through basic education. It provides an opportunities for human capabilities of all children through provision of community owned education in a mission mode. SSA's main aim is to bridge social, regional and gender gaps and its special focus on girl's education and disabled children with the active participation of community in the management of schools. A group that forms a very important part of equity issues under SSA is Children with special needs (CWSN). The key thrust of SSA will be on providing Inclusive education to all children with special needs in general schools. SSA ensures that every child with special needs, irrespective of the kind, category and degree of disability, is provided quality inclusive education. It will also support a wide range of approaches, options and strategies for education of children with special needs. This includes special training in the form of school readiness programmes for CWSN, education through special schools, Home based schooling, community based rehabilitation(CBR). The ultimate aim of SSA would be to mainstream all CWSN in neighbourhood schools. Inclusive education for CWSN under SSA seeks to develop full potentiality of each child with a disability for emphasizing on ending all forms of discrimination and promoting effective participation of all. Thus inclusion of CWSN has to be seen in terms of physical, social and quality of access.

\section{Physical Access to Children with Special Needs}

1. Mapping of CWSN,

2. Assessment of CWSN for Mapping of Needs,

3. Educational Placement,

4. Aids and Appliances,

5. Removal of Architectural Barriers.

Quality of Access to Children with Special Needs

1. Support Services,

2. Teacher Training,

3. Resource Support,

4. Curricular Access,

5. Individualized Educational Plan (IEP),

6. Building Synergy with Special Schools.

Social Access to Children with Special Needs

1. Parental Training and Community Mobilization

2. Peer Sensitation.

\section{SSA And CWSN in Puducherry}

The Union Territory of Puducherry ranks seventh in the place of Literacy Rate percentage next to Kerala, Lakshadweep, Mizoram, Tripura, Goa and Daman\& Diu. As per the 2011 census, the literacy rate for the Union Territory of Puducherry is $86.55 \%$ with $92.12 \%$ males and $81.22 \%$ females being literates. Among the districts of the U.T of Puducherry, Mahe has the highest literacy rate with $98.35 \%$ and Yanam, the lowest literacy rate with $80.26 \%$. 9, 66,600 persons are literates in the Union territory of Puducherry, of which 5, 02,575 persons are males and 4, 64,025 persons are females. The highest numbers of literates $(3,48,524)$ are living in Puducherry, whereas the lowest numbers of literates $(19,932)$ are living in Yanam. The details of No.of literates, literacy rate of Puducherry UT and No. of schools in Puducherry UT are given in the tables 6.1, 6.2 and 6.3 respectively.

Table 6.1: Number of Literates in Puducherry UT

\begin{tabular}{|l|c|c|c|}
\hline \multicolumn{1}{|c|}{ District } & Persons & Males & Females \\
\hline Puducherry & $7,33,075$ & $3,84,551$ & $3,48,524$ \\
\hline Karaikal & $1,56,988$ & 81,040 & 75,948 \\
\hline Mahe & 36,730 & 16,798 & 19,932 \\
\hline Yanam & 39,807 & 20,186 & 19,621 \\
\hline Puducherry UT & $\mathbf{9 , 6 6 , 6 0 0}$ & $\mathbf{5 , 0 2 , 5 7 5}$ & $\mathbf{4 , 6 4 , 0 2 5}$ \\
\hline
\end{tabular}

Source: 2011Literacy Census, Government of India 
Table 6.2: Of Puducherry

\begin{tabular}{|c|c|c|c|}
\hline District & Persons & Males & Females \\
\hline Puducherry & 86.13 & 92.07 & 80.40 \\
\hline Karaikal & 87.83 & 93.36 & 82.61 \\
\hline Mahe & 98.35 & 99.24 & 97.61 \\
\hline Yanam & 80.26 & 83.63 & 77.07 \\
\hline $\begin{array}{c}\text { Puducherry } \\
\text { UT }\end{array}$ & $\mathbf{8 6 . 5 5}$ & $\mathbf{9 2 . 1 2}$ & $\mathbf{8 1 . 2 2}$ \\
\hline
\end{tabular}

Literacy Rate (\%)

UT

Source: 2011 Literacy Census, Government of India

Table 6.3: Number of Schools in Puducherry UT

\begin{tabular}{|l|c|c|c|c|}
\hline \multicolumn{1}{|c|}{ District } & Government & Govt. Aided & $\begin{array}{c}\text { Govt. } \\
\text { Unaided }\end{array}$ & Total \\
\hline Puducherry & 284 & 26 & 169 & 479 \\
\hline Karaikal & 107 & 7 & 47 & 161 \\
\hline Mahe & 18 & 0 & 13 & 31 \\
\hline Yanam & 24 & 1 & 7 & 32 \\
\hline $\begin{array}{l}\text { Puducherry } \\
\text { UT }\end{array}$ & $\mathbf{4 3 3}$ & $\mathbf{3 4}$ & $\mathbf{2 3 6}$ & $\mathbf{7 1 0}$ \\
\hline
\end{tabular}

Source: Directorate of School Education, Government of Puducherry

There are 710 schools in the Union Territory of Puducherry. Out of these 710 schools, 433 schools are government schools, 34 are government aided and 236 unaided schools. Among 467 government and government aided schools. Sarva Shiksha Abhiyan (SSA) have been launched in the government and government aided schools in the academic year 2002-03 in the Union Territory of Puducherry, though its inception in 2001-02 at national level, due to the late formation of Village Education Committee and Parents Teachers Association. Literacy is not a challenging issue in Puducherry UT, whereas the main aim of Sarva Shiksha Abhiyan is to provide quality basic education and bridge social and gender gaps through providing Integrated and Inclusive Education to all children with special needs in general schools. With the implementation of Sarva Shiksha Abhiyan in Puducherry UT, the enrollment rate in the primary and upper primary has increased. In the primary section, 36,452 students enrolled, of which 17,431 are boys and 19111 are girls, 35405 students enrolled in upper primary section, of which 17,580 are boys and 17825 are girls.

Since its inception, assessment camp and conferences/workshops under inclusive education for disabled children have been organized under Early Childhood Care and Education (ECCE) and NonGovernmental organizations. 2983 CWSN were identified and enrolled in general schools in 2008-2009. In the year 2009-2010, 1401 CWSN were identified and enrolled in the general schools in Puducherry. A total of 2996 children with special needs were identified through a Household Survey conducted during 2009-2010 under SSA, out of these 2859 CWSN enrolled in the main stream schools and 110 CWSN covered through Home based education in the union territory of Puducherry. The details are given in the tables 6.4, 6.5, 6.6 and 6.7 respectively

Table 6.4: Enrollment of CWSN in Schools/ Special Schools/ Day Care Center/ Homes/Home Based in Puducherry UT

\begin{tabular}{|l|c|c|c|c|c|c|c|c|c|c|}
\hline \multirow{2}{*}{ District } & \multicolumn{2}{|c|}{ Puducherry } & \multicolumn{2}{|c|}{ Karaikal } & \multicolumn{2}{c|}{ Mahe } & \multicolumn{2}{c|}{ Yanam } & \multicolumn{2}{c|}{ Total } \\
\hline & Boys & Girls & Boys & Girls & Boys & Girls & Boys & Girls & Boys & Girls \\
\hline In Seeing & 143 & 148 & 122 & 99 & 17 & 7 & 4 & 7 & $\mathbf{2 8 6}$ & $\mathbf{2 7 1}$ \\
\hline Hearing & 58 & 56 & 20 & 25 & 5 & 1 & 1 & 8 & $\mathbf{8 4}$ & $\mathbf{9 0}$ \\
\hline Moving & 77 & 49 & 34 & 19 & 8 & 3 & 17 & 13 & $\mathbf{1 3 6}$ & $\mathbf{8 4}$ \\
\hline M.R & 60 & 44 & 47 & 20 & 7 & 6 & 6 & 8 & $\mathbf{1 2 0}$ & $\mathbf{7 8}$ \\
\hline Others & 25 & 14 & 6 & 2 & 4 & 2 & 1 & 0 & $\mathbf{3 6}$ & $\mathbf{1 8}$ \\
\hline
\end{tabular}


Inclusion Of Disabled Children in General Schools in Puducherry

\begin{tabular}{|l|c|c|c|c|c|c|c|c|c|c|}
\hline Speech & 45 & 22 & 29 & 15 & 4 & 2 & 15 & 5 & $\mathbf{9 3}$ & $\mathbf{4 4}$ \\
\hline $\begin{array}{l}\text { Multi } \\
\text { type }\end{array}$ & 19 & 8 & 22 & 4 & 3 & 0 & 3 & 2 & $\mathbf{4 7}$ & $\mathbf{1 4}$ \\
\hline Total & $\mathbf{4 2 7}$ & $\mathbf{3 4 1}$ & $\mathbf{2 8 0}$ & $\mathbf{1 8 4}$ & $\mathbf{4 8}$ & $\mathbf{2 1}$ & $\mathbf{4 7}$ & $\mathbf{4 3}$ & $\mathbf{8 0 2}$ & $\mathbf{5 9 9}$ \\
\hline
\end{tabular}

Source: Annual Report (2009-2010 \& 2010-2011). Sarva Shiksha Abhiyan, Directorate of School Education.

Government of Puducherry

Table 6.5: Details of Enrolment in the Field of Special Education

\begin{tabular}{|l|c|c|c|c|}
\hline SI.No & District & $\mathbf{2 0 0 8 - 2 0 0 9}$ & $\mathbf{2 0 0 9 - 2 0 1 0}$ & $\mathbf{2 0 1 0 - 2 0 1 1}$ \\
\hline 1 & Puducherry & 1917 & 768 & 2174 \\
\hline 2 & Karaikal & 585 & 464 & 498 \\
\hline 3 & Mahe & 89 & 79 & 79 \\
\hline 4 & Yanam & 392 & 90 & 108 \\
\hline Total & UT of Puducherry & $\mathbf{2 9 8 3}$ & $\mathbf{1 4 0 1}$ & $\mathbf{2 8 5 9}$ \\
\hline
\end{tabular}

Source: Annual Report (2009-2010 \& 2010-2011). Sarva Shiksha Abhiyan, Directorate of School Education. Government of Puducherry

Table 6.6: District Progress on Inclusive Education in Puducherry UT in 2010-2011

\begin{tabular}{|l|c|c|c|c|c|}
\hline & Puducherry & Karaikal & Mahe & Yanam & Total \\
\hline No of CWSN Identified & 2264 & 518 & 79 & 135 & 2996 \\
\hline $\begin{array}{l}\text { No of CWSN enrolled in } \\
\text { Schools }\end{array}$ & 2174 & 498 & 79 & 108 & 2859 \\
\hline $\begin{array}{l}\text { No of CWSN covered } \\
\text { through school Readiness } \\
\text { Programme }\end{array}$ & 0 & 0 & 0 & 27 & 27 \\
\hline $\begin{array}{l}\text { No of CWSN covered } \\
\text { through home based } \\
\text { education }\end{array}$ & 90 & 20 & 0 & 0 & 110 \\
\hline $\begin{array}{l}\text { No. of CWSN provided aids } \\
\text { and appliances through } \\
\text { NIEPMD\&Worth trust }\end{array}$ & 235 & 0 & 0 & 0 & 235 \\
\hline $\begin{array}{l}\text { No of NGOs involved } \\
\text { No of RTs appointment }\end{array}$ & 4 & 2 & 0 & 2 & 8 \\
\hline Total no of schools & 220 & 82 & 18 & 23 & 343 \\
\hline $\begin{array}{l}\text { No of schools made barrier } \\
\text { free }\end{array}$ & 78.5 & 75.9 & 100 & 95.8 & 79.8 \\
\hline $\begin{array}{l}\% \text { of schools made barrier } \\
\text { free }\end{array}$ & 3 & 108 & 18 & 24 & 430 \\
\hline
\end{tabular}

Source: Annual Report (2010-2011). Sarva Shiksha Abhiyan, Directorate of School Education. Government of Puducherry

Table 6.7: Category Wise Progress in Inclusive Education (2010-2011) In Puducherry UT

\begin{tabular}{|c|l|c|c|c|c|}
\hline SI.No & \multicolumn{1}{|c|}{ Category } & $\begin{array}{c}\text { No. } \\
\text { Identified }\end{array}$ & $\begin{array}{c}\text { No. Enrolled in } \\
\text { Mainstream } \\
\text { Schools }\end{array}$ & $\begin{array}{c}\text { No. Enrolled in } \\
\text { AIE/EGS }\end{array}$ & $\begin{array}{c}\text { covered } \\
\text { through } \\
\text { HBE }\end{array}$ \\
\hline 1 & Low Vision & 171 & 171 & 0 & 0 \\
\hline 2 & TB & 108 & 108 & 0 & 0 \\
\hline 3 & Hearing Impairment & 532 & 532 & 0 & 0 \\
\hline 4 & Seeing Impairment & 112 & 112 & 0 & 0 \\
\hline 5 & Other Impairment & 592 & 592 & 0 & 0 \\
\hline 6 & Cerebral Palsy & 157 & 157 & 0 & 0 \\
\hline 7 & Mentally Retarded & 334 & 240 & 27 & 67 \\
\hline 8 & Learning Disability & 557 & 557 & 0 & 0 \\
\hline
\end{tabular}


Inclusion Of Disabled Children in General Schools in Puducherry

\begin{tabular}{|c|l|c|c|c|c|}
\hline 9 & Multiple Disability & 204 & 161 & 0 & 43 \\
\hline 10 & Autism & 230 & 230 & 0 & 0 \\
\hline & Total & $\mathbf{2 9 9 7}$ & $\mathbf{2 8 6 0}$ & $\mathbf{2 7}$ & $\mathbf{1 1 0}$ \\
\hline
\end{tabular}

Source: Annual Report (2010-2011). Sarva Shiksha Abhiyan, Directorate of School Education. Government of Puducherry

In the UT of Puducherry 171 low vision students were provided with high 5 spectacles and magnifier. Rs. 7500 worth Braille kits supplied to totally blind children. 532 hearing impaired children and 112 speech impaired children are undergoing physiotherapy; CP chairs were given to CWSN undergoing Physiotherapy and 9 are recommended for orthosis of the $591 \mathrm{OH}$ students, 143 were given Physiotherapy, 56 were referred to NIEPMD for mobility devices and they were provided with CTEV Boot Wear and spinal braces. In collaboration with NGOs such as Sathya Special School, Sadha Special School, etc., in Puducherry UT conducted inclusive sports meets, cultural activities and celebrating festivals. Assessment camps are conducted in and around Puducherry in collaboration with NIEPMED Muthukadu. CWSN identified from schools were assessed by a team of professionals with respect to type of disability, degree of disability and they are enrolled in the mainstream schools. Medical assessment camps are also conducted in and around Puducherry in collaboration with Aravind Eye Hospital to identify low vision and visually impaired students and the diagnosed CWSN were provided surgery, high powered spectacles, magnifiers, cataract with respect to disability. Rs.7.50 lakh was sanctioned for upgrading the existing toilets to disabled friendly toilet in inclusive schools, Where LV students are studying, 25 schools in Puducherry, 15 in Karaikal, 5 in Mahe and 5 in Yanam were identified and construction has begun. 1780 general teachers for 5 days were trained in handling CWSN and 120 teachers will undergo training from March 2011. The details of beneficiaries under various agencies are given in the table 6.8.

1. Coverage of CWSN $100 \%$

2. 8 resource teachers appointed

3. A total of 1900 aids and appliances have been provided to CWSN

4. $\quad 1780$ general teachers have been trained through mass teacher training

5. 120 teachers trained through 90 day RCI foundation course

6. $343(79.80 \%)$ schools provided with ramps and handrails

Table 6.8: Details of CWSN Beneficiaries

\begin{tabular}{|c|l|c|c|}
\hline S.No & \multicolumn{1}{|c|}{ Aids Recommended } & $\begin{array}{c}\text { No. of } \\
\text { Beneficiaries }\end{array}$ & Agency \\
\hline 1 & Physiotherapy & 48 & JIPMER \\
\hline 2 & Surgery & 6 & GH \\
\hline 3 & Othosis & 12 & NIEPMED \\
\hline 4 & Prothesis & 9 & NIEPMED \\
\hline 5 & Posterior tube & 2 & NIEPMED \\
\hline 6 & Prosthetic Finger & 1 & NIEPMED \\
\hline 7 & CTEV Boot/ Footwear & 6 & NIEPMED \\
\hline 8 & Cock up Splint & 11 & NIEPMED \\
\hline 9 & Cosmetic Glove & 2 & NIEPMED \\
\hline 10 & Cosmetic Hand & 4 & NIEPMED \\
\hline 11 & Mechanical hand & 1 & NIEPMED \\
\hline 12 & Modified shoe/ footwear & 4 & NIEPMED \\
\hline 13 & Spinal Brace & 9 & NIEPMED \\
\hline 14 & Splint & 2 & NIEPMED \\
\hline 15 & Hyper extension shoe & 8 & SSA \\
\hline 16 & Wheel chair & $\mathbf{1 4 0}$ & \\
\hline & \multicolumn{2}{|c|}{ Total } & Directorate \\
\hline
\end{tabular}

Source: Annual Report (2010-2011). Sarva Shiksha Abhiyan, Directorate of School Education. Government of Puducherry

\section{Conclusion}

Mainstreaming of the disabled is must as countries cannot afford to waste the talents of a vast section of children just because they have some disability. There are some instances where disabled children have excluded in various fields. Individuals with disabilities often encounter various forms of discriminations in their daily lives, which frequently limits their full participation in society. As a result some would suggest that these citizens are" marginalized and excluded from the mainstream society. In Puducherry Children with special needs have been provided good ambience, infrastructure and education in the mainstream schools since the implementation of Sarva Shiksha Abhiyan. On the whole Sarva Shiksha Abhiyan in Puducherry UT has 
enhanced the condition of Children with special needs, in particular the disabled children, it has provided barrier free infrastructure, aids and appliances and special teachers to understand the learning needs of disabled children in a diversified classroom.

\section{Reference}

[1]. Arunachalam, N. (2010). Special Education to Inclusive Education: A paradigm Shift. In Dr. Arunachalam, Educating Children with Special Needs. New Delhi: APH publishing Corporation.

[2]. Baghat, J.L. (2009). Inclusive Education for the Disabled. In J.S.Saini \& Amit Goyal, Empowering Disabled (pp. 39-45). Chandigarh: Abhishek Publications

[3]. Agarwal, Rashmi \& Rao, B.V.L.N. (2007). Education for Disabled Children. Delhi: Shipra Publications.

[4]. Abstracts of Research studies in Elementary Education (2003-2009).Research Evaluation Study Unit. Technical support Group for Sarva Shiksha Abhiyan. EdCil (India) Ltd.

[5]. Annual Report 2009-2010. Sarva Shiksha Abhiyan, Directorate of School Education. Government of Puducherry

[6]. Annual Report 2010-2011.Sarva Shiksha Abhiyan, Directorate of School Education. Government of Puducherry

[7]. Dash, Neena (2006).Inclusive education for Children with Special Needs. New Delhi: Atlantic Publishers

[8]. Mohanty, Jagannath (2002). Primary and Elementary Education. New Delhi: Deep and Deep Publications

[9]. Sarva Shiksha Abhiyan: Framework for Implementation. Department of School Education and Literacy. Ministry of Human Resource Development. March 2011

[10]. Sharma, Kaushal (2007). Inclusive Education for PWDs: An Everyone's Challenges. In Kaushal Sharma \& B.C.Mahapatra, Emerging Trends in Inclusive Education. New Delhi: IVY Publications.

[11]. Kar, Chintamani (1992). Exceptional Children: Their psychology and Education. New Delhi: Sterling Publishers Private limited 